
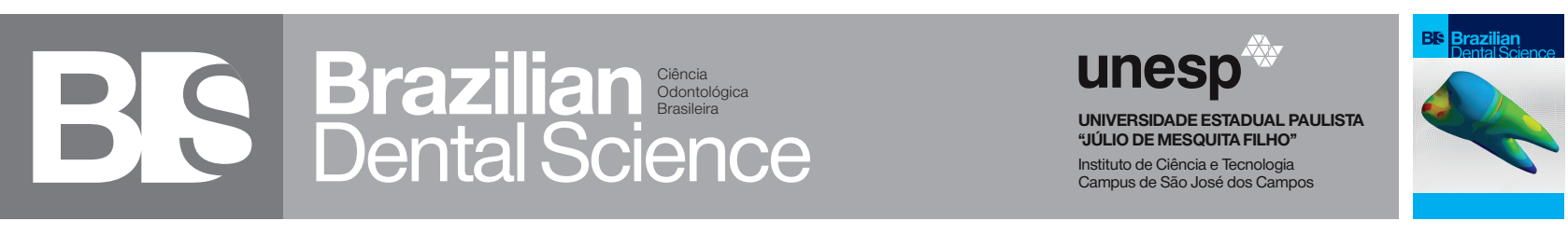

\title{
Assessment of the opening diameter of the incisive foramen as a parameter for gender and age estimation
}

\author{
Avaliação do diâmetro de abertura do forame incisivo como parâmetro de estimativa de sexo e idade
}

Paulo Henrique Viana PINTO ${ }^{1}$, Maria Ângela Arêa Leão FERRAZ ${ }^{1}$, Severino Cavalcante de SOUSA JÚNIOR ${ }^{2}$, Jean de Pinho MENDES ${ }^{1}$, André Luiz Ferreira COSTA ${ }^{3}$, Sérgio Lúcio Pereira de Castro LOPES ${ }^{4}$, Antonione Santos Bezerra PINTO ${ }^{1}$

1 - State University of Piauí - Parnaíba - PI - Brazil.

2 - Federal University of Piauí - Minister Reis Velloso Campus - Parnaíba - Piauí - Brazil.

3 - Department of Orthodontics and Radiology - University of São Paulo City (UNICID) - São Paulo - SP - Brazil.

4 - São Paulo State University (Unesp) - Institute of Science and Technology - São José dos Campos - Department of Diagnosis and Surgery- SP - Brazil.

\begin{abstract}
Objective: To analyse the opening diameter of incisive foramen as a parameter for gender and age estimation by using cone beam computed tomography (CBCT). Material and Methods: After approval by the local research ethics committee, CBCT images were obtained from the dental database of a diagnostic centre and then selected. Images suggesting presence of periapical lesions and periodontal changes were excluded, as well as those of patients undergoing orthodontic treatment, with trauma to the mid-facial third, with cleft/lip palate, cranial or syndromic morphological changes, or even absence of one of the upper incisors. The images of male and female patients were distributed according to age groups (i.e. $10-30$ years, $31-50$ years, and 51 years or older) and then assessed twice and independently by three surgeon-dentists with experience in radiology by means of the XoranCat ${ }^{\circledR}$ software. The resulting data were tabulated and statistically analysed by using the SAS ${ }^{\circledR}$ software (version 2003) - PROC GLM for mixed generalised models - and Tukey's test for comparison of the mean values at 5\% significance level. Results: Considering the methodology used, the results have demonstrated no statistically significant difference in the method for gender estimation. However, it was observed that there was a gradual increase in the mean values as the age advances in the majority of the age groups for both males and females, with a statistically significant difference $(\mathrm{P}<0.05)$ regarding age estimation. Conclusion: The use of incisive foramen as a gender parameter has had a limited forensic value, but it is an innovative approach in the process of age estimation.
\end{abstract}

\section{KEYWORDS}

Dentistry; Human identification; Anatomy; Computed tomography.

\section{RESUMO}

Objetivo: Analisar o diâmetro de abertura do forame incisivo como parâmetro de estimativa de sexo e idade utilizando exames de Tomografia Computadorizada de Feixe Cônico (TCFC). Material e Métodos: Mediante aprovação do Comitê de Ética em Pesquisa, selecionaramse exames de TCFC originários do arquivo odontológico de um determinado centro diagnóstico. Foram excluídos os exames que sugerissem presença de lesões periapicais, alterações periodontais, bem como de pacientes sob tratamento ortodôntico, com trauma no terço médio facial, com fissuras palatinas, alterações morfológicas em crânio ou sindrômicos, ou ainda ausência de qualquer um dos dentes incisivos superiores. As imagens foram distribuídas segundo faixa etária de 10 a 30 anos, 31 a 50 anos, 51 anos ou mais, de ambos os sexos, e avaliadas duas vezes por três Cirurgiões-Dentistas radiologistas de forma independente utilizando o software XoranCat®. Os dados foram tabulados e analisados estatisticamente através do Software SAS®, versão 2003, por meio do PROC GLM, modelos mistos generalizados e o teste de comparação de médias foi o Tukey a 5\% de significância. Resultados: Considerando a metodologia adotada, os resultados não demonstraram diferença estatisticamente significante que pudesse sugerir um método de estimativa de sexo. Porém, percebeu-se que houve um aumento gradativo das médias encontradas conforme o avanço da idade para ambos os sexos na maioria dos grupos, além de uma diferença estatisticamente significante $(\mathrm{p}<0,05)$ em relação à estimativa de idade. Conclusão: A utilização do forame incisivo como parâmetro dimórfico entre sexos demonstrou limitado valor forense, mas apresenta uma proposta inovadora no processo de estimativa de idade.

\section{PALAVRAS-CHAVE}

Odontologia; Identificação Humana; Anatomia; Tomografia Computadorizada. 


\section{INTRODUCTION}

$\mathrm{F}$ orensic dentistry comprises a primary method of human identification enabling one to scientifically support the identity of an unknown corpse mainly due to the uniqueness of the dental arches [1,2]. Moreover, because maxillary bones and dental elements are highly mineralised and surrounded by soft tissues, they tend to resist to adverse environmental conditions, thus preserving anatomical accidents and characters for long periods of time $[3,4]$.

In the process of human identification, the determination of gender and age is a key step for establishing a biological profile, which is essential to reduce the sample to a lower number of possible identities $[5,6]$. However, this procedure is challenged with situations in which there are a few bone fragments or remnants of pelvis or skull $[3,5,6]$. In this context, research on forensic dentistry and anthropology have associated the use of image technology to the study of bone anatomy for obtaining clues which can guide the estimation of gender and age in such situations [6-8].

In this way, CBCT has been widely used as it allows three-dimensional visualisation of the anatomical shape, relationship and position of a series of bone structures and cavities by providing detailed images with minimum distortion, which enables a more reliable study of the bone morphology and morphometry $[2,3,6]$.

Due to these advantages, studies have demonstrated that it is possible to correlate anatomical variations in the trajectory and shape of intra-osseous canals and neuro-vascular bundles with their respective foramina by using methods for estimation of gender and age [9-13], since the bone tissue remodels and adapts itself to metabolic influences as well as to functional [14] and hormonal demands occurring during the body's physiological development [12].

Although there are considerably reliable methods for estimation of gender $[8,15]$ and age $[16,17]$ using dental and osseous elements, it is necessary that other methodologies be proposed to aid in cases of dental absence or bone fragmentation resulting of severe traumas, such as mass accidents and explosions [5-7]. Therefore, the present work was aimed at using CBCT to measure the opening diameter of incisive foramen and to analyse its correlation as a parameter for gender and age estimation.

\section{MATERIAL AND METHODS}

This is a quantitative and qualitative study performed with CBCT images, which were obtained from a dental diagnostic centre. It was approved by the research ethics committee of the State University of Piaui according to protocol number 66061417.8.0000.5209 and after the patients who held the dental images signed an informed consent form. The present study has targeted all CBCT images of patients who underwent this examination between 2011 and January 2017 for other purposes. As for data collection, an electronic spreadsheet for recording information on the patients was prepared by using the Microsoft Excel ${ }^{\circledR}$ version 2010. All the images had been acquired with a cone beam computed tomography equipment (GXCB- $500^{\mathrm{TM}}$, powered by i-CAT $\AA$ ) operating at field of view (FoV) of $16 \times 6.0 \mathrm{~cm}$ and voxel size of 0.25 millimeter.

Images were selected according to the following exclusion criteria: patients with periapical lesions or lacking any of the upper 
central and lateral incisors; patients with periodontitis; patients undergoing orthodontic treatment; patients with trauma to the midfacial third; patients with cleft/lip palate; and patients with cranial or syndromic morphological changes. The images of male and female patients were distributed according to age groups of 1030 years, 31-50 years, and 51 years or older and then assessed twice and independently by three surgeon-dentists with experience in radiology and CBCT imaging assessment. The CBCT images were assessed under low-light conditions.

The measurement of the opening diameter of the incisor foramen was made by using the XoranCat ${ }^{\circledR}$ software (Xoran Technologies, Ann Arbor, MI, USA) at multiplanar reconstruction (MPR window) according to the following protocol for standardisation of the section to be measured:

1) The sagittal plane was initially adjusted to the axial section window by using the sagittal reference line within the window. One could identify the axial section where the anterior nasal spine was visualised in its greatest extension, with the sagittal reference line being taken to it and the section rotated, and if necessary, dividing the anterior nasal spine symmetrically as much as possible (Figure 1).

2) By adjusting the sagittal plane position, one could observe the section showing the incisor foramen and nasopalatine canal in its greatest extension (median sagittal section). The section was rotated so that the buccal cortical bone of the local alveolar ridge could be in vertical position, which was determined by guiding this section according to the coronal reference line (Figures 2A and 2B). After these adjustments in the median sagittal section, one could identify the most upper point of the palatal cortical bone of the incisor foramen and the axial reference line could be taken to this point so that the axial section was coincident with it (Figures 2C and 2D).
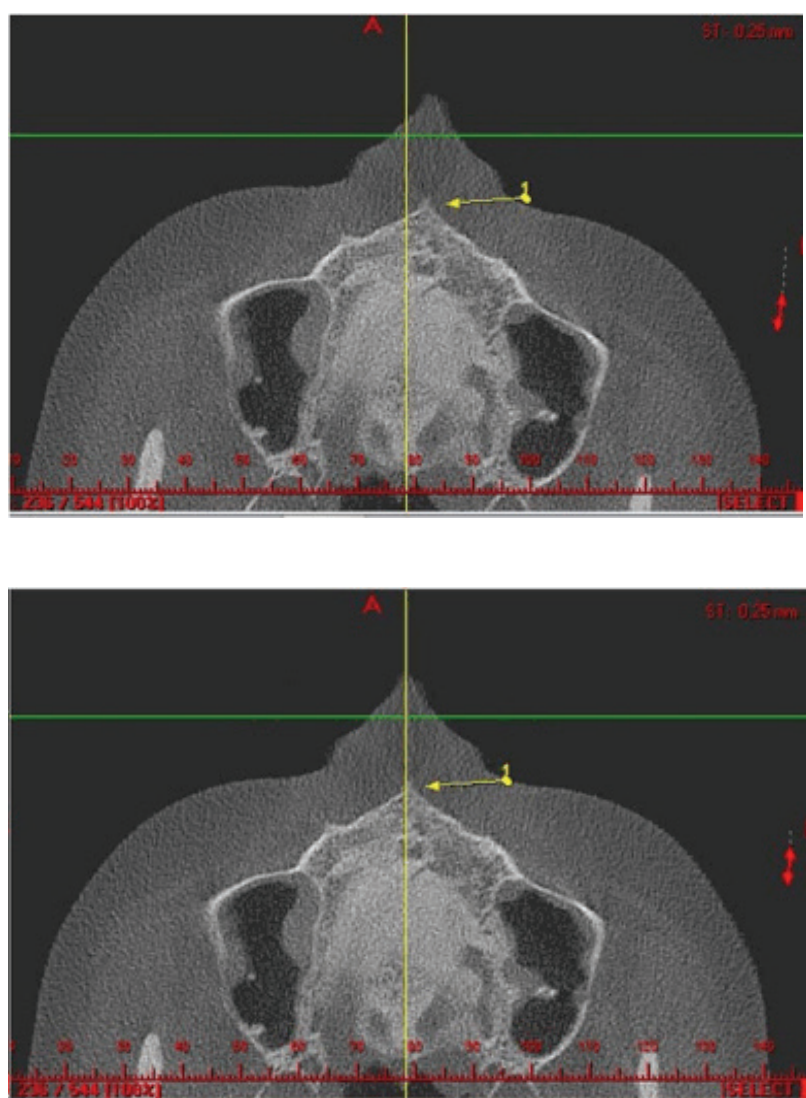

Figure 1 - Axial sections showing the anterior nasal spine (arrow 1) and sagittal reference line showing section rotation as a reference of this structure, making it symmetric. 

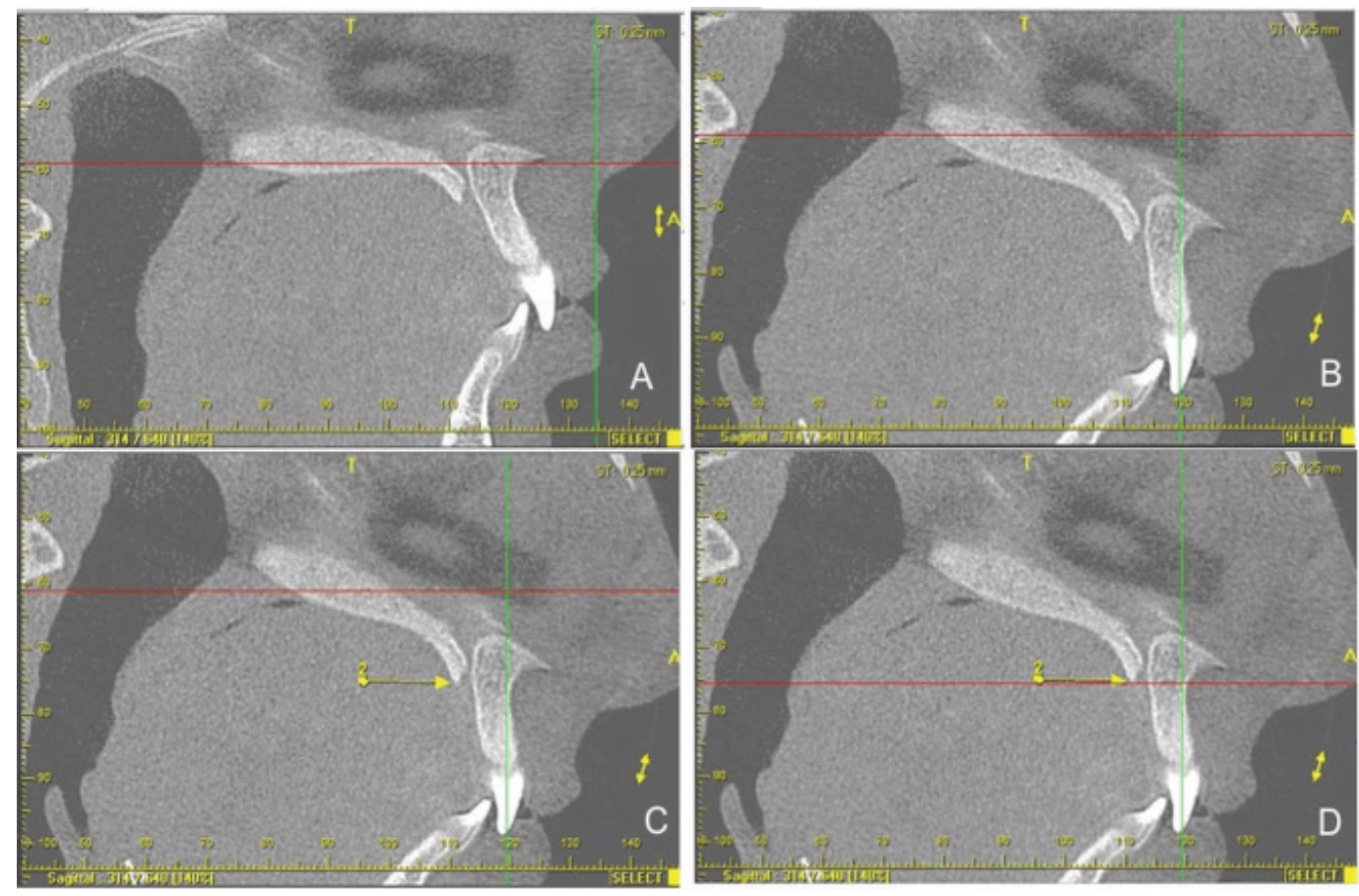

Figure 2 - Sagittal sections: A) Median sagittal section showing incisor foramen and nasopalatine canal. B) Rotation of median sagittal section showing buccal cortical bone of the alveolar ridge coinciding with the coronal reference line. C) Identification of the most upper point of the palatal cortical bone of the incisor foramen (arrow 2). D) Axial reference line coinciding with point A2, determining the axial section for measurements

3) In this axial section, measurements of the incisor foramen were made in order to standardise the sites to be measured in all images (Figure 3).

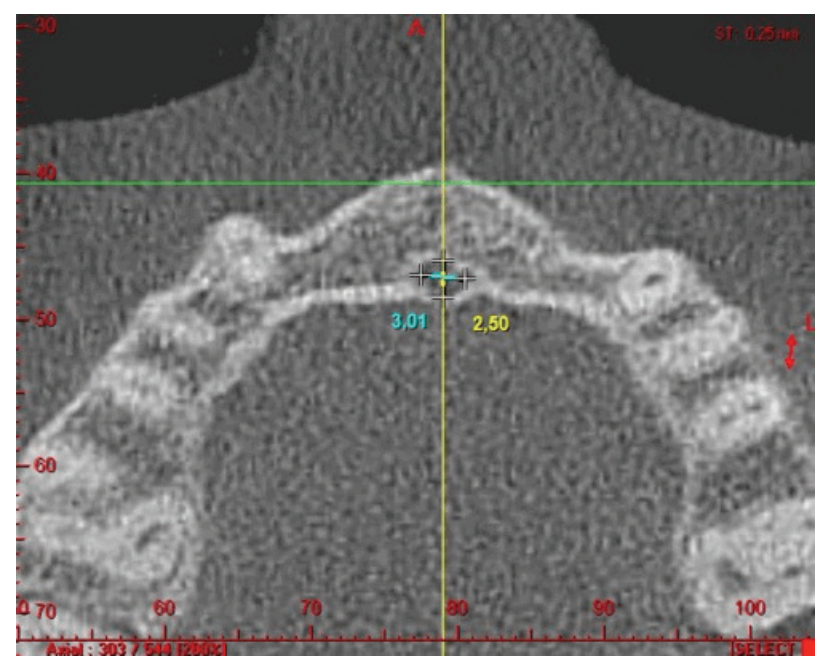

Figure 3 - Axial reference section and measurements of the incisor foramen.
The measurements were made following alignment of the planes and the sagittal section was rotated so that the upper central incisors were positioned along the long axis vertically. Next, by using the ruler tool, the anteroposterior distance was measured considering the apical distance of $2 \mathrm{~mm}$ between incisor and its cemento-enamel junction. Next, the axial section was taken to this point so that the distance of $2.0 \mathrm{~mm}$ from the cemento-enamel junction was maintained in each image, thus allowing the latero-lateral distance to be determined later.

The data gathered were tabulated into electronic spreadsheets (Microsoft Excel ® version 2010) and then statistically analysed by using the SAS software version 2003 and PROC GLM for mixed generalised models. Tukey's test was used for comparison of the mean values (TCM) at 5\% significance level, with the results being shown in graphs and tables for better visualisation and comparison. 


\section{RESULTS}

In this work, the researchers have divided the sample (n) by gender and into three age groups, corresponding to a total of 659 CBCT images (Table 1). The patients were selected according to inclusion and exclusion criteria (Figure 4). The images were analysed based on a framework of reference axes in the axial, coronal and sagittal orientations.

Table 1 - Distribution of the sample according to gender and age of the patients

\begin{tabular}{ccc} 
& Gender & \\
& & Fale \\
& Age Group \\
\hline Group I & Group II & Group III \\
10 to 30 years & 31 to 50 years & 51 years or older
\end{tabular}

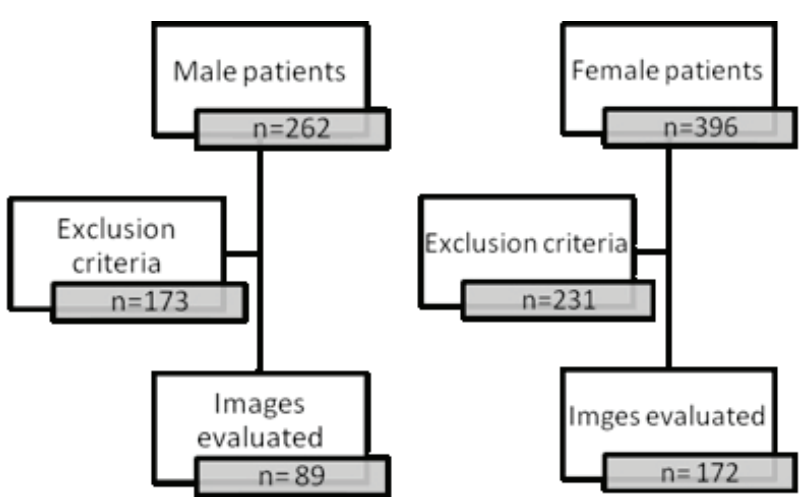

Figure 4 - Flowcharts: Total of images resulting from the selection based on inclusion and exclusion criteria

The measurements values of the opening diameter of incisor foramen in the anteroposterior and latero-lateral orientations are, respectively, listed in Figures 5 and 6 for both genders and age groups.

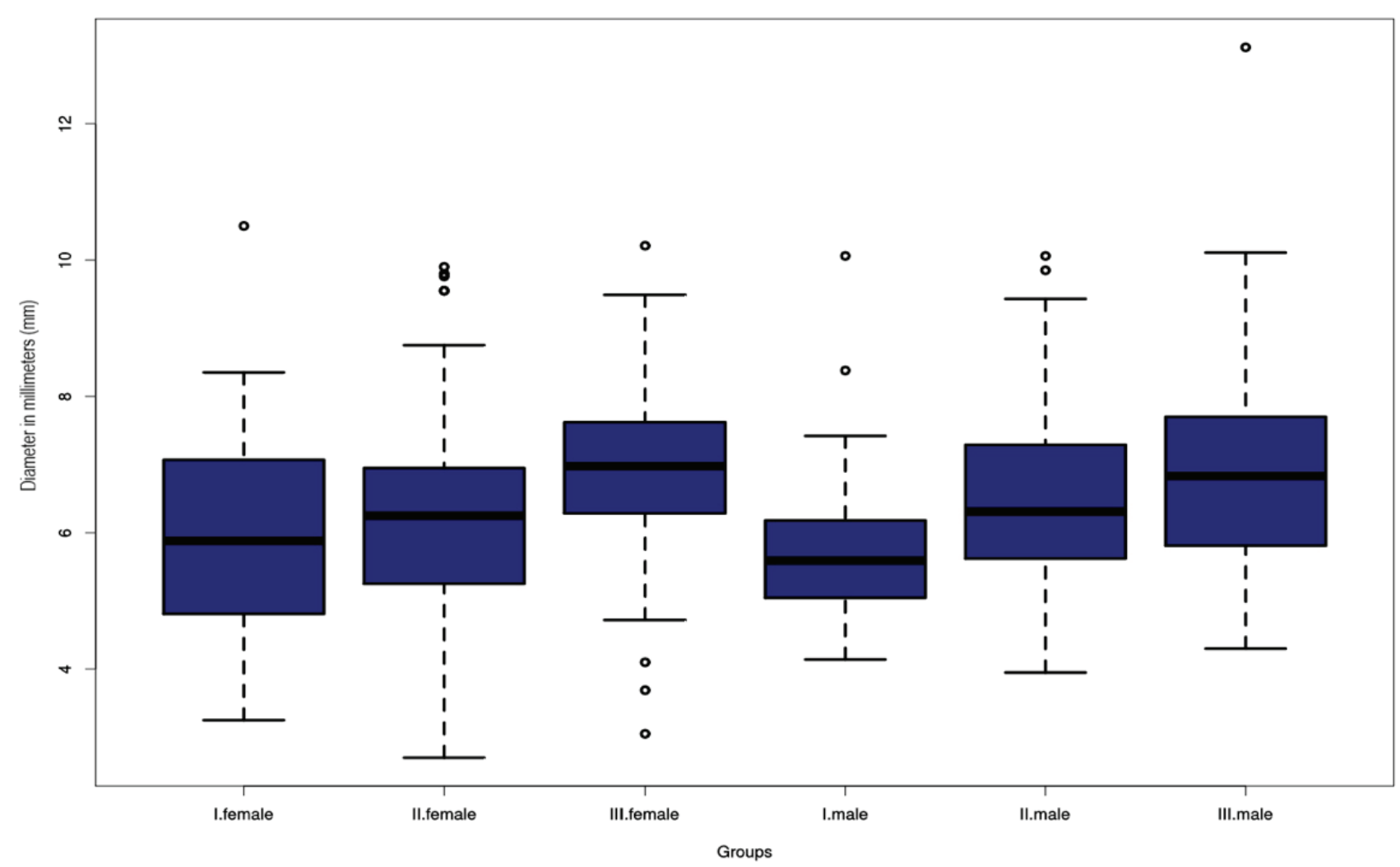

Figure 5 - Graph 1. Values of the antero-posterior opening diameter of the incisor foramen Group I - 10 to 30 years; Group II - 31 to 50 years; Group III - 51 years or older 


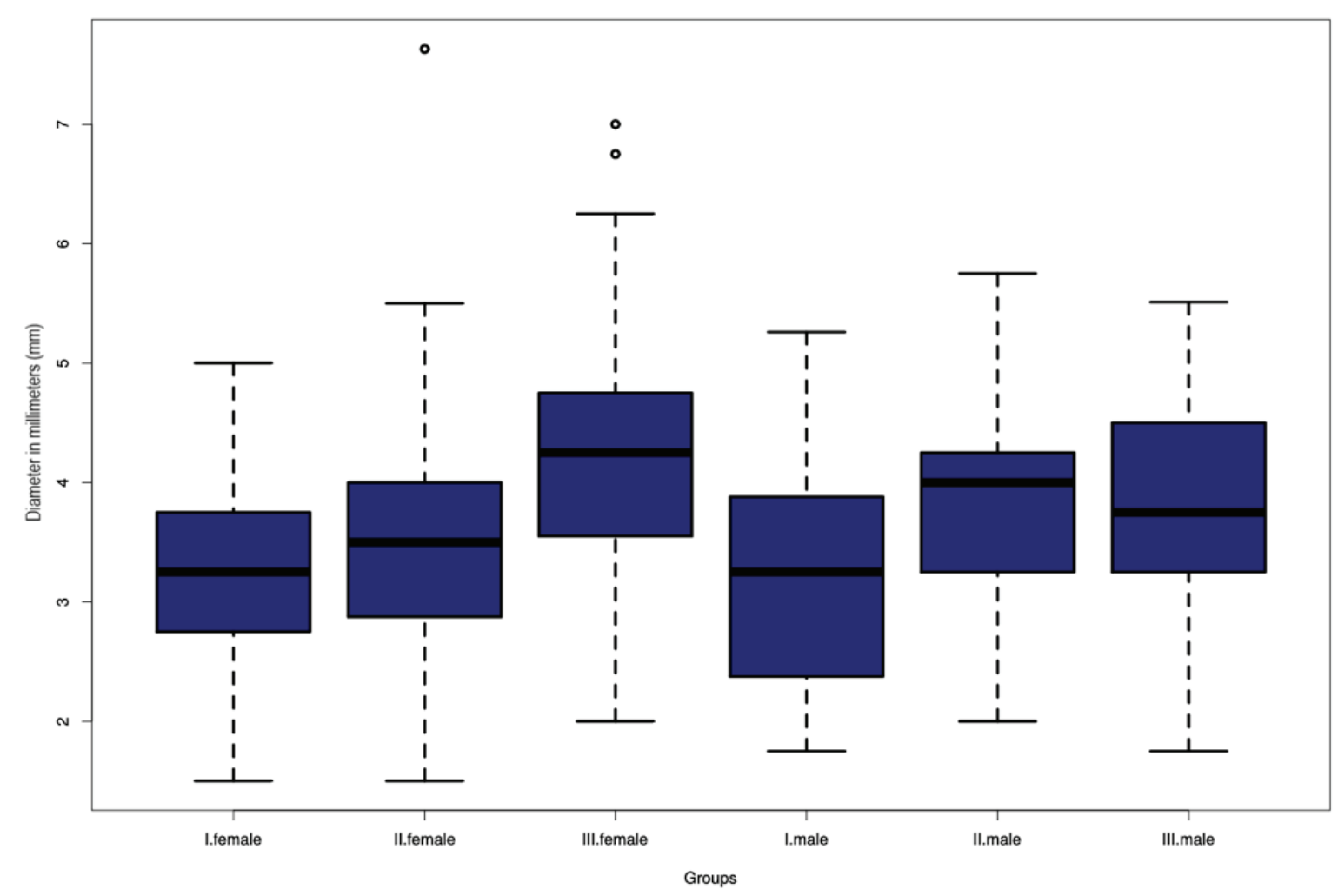

Figure 6 - Graph 2. Values of the latero-lateral opening diameter of the incisor foramen Group I - 10 to 30 years; Group II - 31 to 50 years; Group III - 51 years or older

Table 2 - Means and P-values of the variables studied

\begin{tabular}{|c|c|c|c|}
\hline \multicolumn{2}{|c|}{ Characteristics } & \multirow{2}{*}{$\begin{array}{c}\text { Means } \\
4.85^{\mathrm{a}}\end{array}$} & \multirow{3}{*}{$\begin{array}{r}\text { P-values } \\
0.1609\end{array}$} \\
\hline \multirow{2}{*}{ Gender } & Male & & \\
\hline & Female & $5.02^{\mathrm{a}}$ & \\
\hline \multirow{3}{*}{ Age groups } & 10 to 30 years & $4.57^{\mathrm{b}}$ & \multirow{3}{*}{$<.0001$} \\
\hline & 31 to 50 years & $4.88^{b}$ & \\
\hline & 51 years or older & $5.45^{\mathrm{a}}$ & \\
\hline \multirow{2}{*}{ Diameter } & Antero-posterior & $6.28^{\mathrm{a}}$ & \multirow{2}{*}{$<.0001$} \\
\hline & Latero-lateral & $3.65^{b}$ & \\
\hline
\end{tabular}

Note: Mean values with letters were equal, not statistically differing between each other, according to Tukey's test at 5\% significance.

Table 3 - Correlations between gender, age group and opening diameters

\begin{tabular}{cccc|}
\hline Characteristics & Gender & Age group & Diameter \\
\hline Gender & 1 & 0,00000 & 0.04442 \\
& & 1.0000 & 0.3439 \\
Age groups & 0.00000 & & 0.19565 \\
& 1.0000 & 1 & $<0.0001$ \\
\hline Diameter & 0.04442 & 0.19565 & 1 \\
& 0.3439 & $<0.0001$ & \\
\hline
\end{tabular}

\section{DISCUSSION}

The technological development of image acquisition methods in the healthcare area has favoured the scientific innovation by enabling studies and analyses to benefit from the copious source of information on human body $[6,18]$. CBCT provides richly-detailed images and, as a result, a series of anatomical regions can be studied and interpreted objectively and in detail. This benefit has been highlighted mainly in the field of forensic sciences because CBCT is an accurate and non-invasive examination method for necropsy of carbonised or fragmented corpses [7,19,20].

In this sense, technological advance has allowed auxiliary techniques to be developed in the process of human identification, either by comparing post-mortem findings to antemortem data or by elaborating further methods of identification, mainly when there are no dental records available for comparison or the person's surgeon-dentist is not known [19,21]. 
Remarkably, the bones forming the skull base are elements with high forensic value due to their anatomical location and peculiar resistance resulting from their osseous density [22]. Specifically, hard palate has these advantages regarding mainly the region of incisor foramen and its intra-osseous canal - elements protected by dental arches and adjacent muscles, which is the reason why we believe in the forensic value of the incisor foramen [22].

In the present study, however, the results have not demonstrated any statistically significant difference which might suggest a method for gender estimation (Table 2). This might be the result of variables affecting the bone physiology, such as the ethnic miscegenation in the Brazilian population $[5,23]$ or differences in the socioeconomic profile of the individuals [24], which were not taken into consideration here. Despite this, the morphological characteristics of the incisor canal (i.e. one or two conduits) and its foramen (i.e. oval or rounded shape) can have an individualising value in the process of human identification as they are structures with considerable morphological variety $[2,18,25]$.

When the correlations between the variables studied (Table 3) were assessed, it was found that there was a statistical significance ( $P$ $<0.05)$ in the correlation between age group and opening diameter. As for age, therefore, one can observe that there was a greater variability in Group II regarding the opening diameter of incisor foramen, which mostly corresponded to a transition period as measurements tend to increase as the age advances. In this way, one can observe that in Group III there was a statistically significant increase in the opening diameter (Table 2) in the antero-posterior and latero-lateral orientations in both male and female patients, possibly as a result of natural hormonal variations with repercussion on osseous trabeculae (Figures 5 and 6).

However, one can emphasise that in Group III some male and female patients had opening measurements close to or even within the limits for the age groups corresponding to Groups I and II. This result can be explained by the presence of different ages distributed into the groups. In sum, one can find that there was a gradual increase in the mean values for both male and female patients regarding antero-posterior diameter, as shown in figures 5 and 6, except the laterolateral diameter in the former as there was a decrease in the mean value observed in Group III (Figure 6). Nevertheless, due to these overlaps, we recommend the use of the opening diameter of incisor foremen with caution as a method for age estimation and, if possible, in association with other parameters $[3,23]$.

The methods for age estimation based on dental and osseous development become more difficult with aging, mainly from the second decade of life $[27,28]$, since bones and teeth are fully formed in the adult phase [16,17,27]. Therefore, the necessity for research on methods with this aim, mainly from the third decade of life, is justified by considering parameters and factors related to different bone structures. This enables the estimation of age and gender with high precision and reliability in cases involving only osseous remnants available for analysis $[5,6,22,23]$.

Inthismanner, theabove-cited considerations were the reasons which led the researchers to opt for separation of the patients into three age groups (i.e. 10-30 years; 31-50 years; and 51 years or older). In addition, we consider that the amount of images used is rather far from the ideal in our study as the great majority of the patients underwent CBCT examination for diagnosis and treatment planning of dental implants only, which significantly reduced our sample (Figure 4).

Additionally, according to Oldrini et al. [27], age estimation becomes less precise with aging because of the increased margin of error regarding the criteria used, which justifies the necessity to use a combination of methods for providing a more precise estimation [22,23]. This observation can be found in this study and explained by the 
overlap of values between the different age groups for both genders [23]. Still, the present work brings an innovative approach, that is, the use of the opening diameter of incisor foramen as a bone variable to be studied in the process of age estimation in adults, mainly in elderly individuals.

Because this is a retrospective analysis, the researchers have opted to not assess the attempt of estimating the age in any of the cases studied by the method described [28]. Although the age estimation may not be notoriously reliable, the incisor foramen is a structure deserving further studies on its auxiliary use for human identification. Moreover, in an attempt to overcome the metric overlaps as well as the ethnic and socio-economic variables observed in the present study, we suggest that multicentre studies addressing different populations should be conducted $[5,6,12]$.

\section{CONCLUSION}

We have concluded that the use of incisor foramen as a gender parameter is not conclusive, but there is a high possibility that this structure can be used for estimating age differences, especially regarding the antero-posterior opening diameter. Moreover, because the incisor foramen can provide objective information, we suggest that further studies on other measurement modalities and its morphological characteristics and intraosseous trajectory should be performed.

\section{REFERENCES}

1. International Criminal Police Organization (ICPO- INTERPOL), 2014. DVI - Disaster Victim Identification Guide. Disponível em: https:// www.interpol.int/INTERPOL-expertise/Forensics/DVI. Acesso em: 22 de fevereiro de 2017.

2. Mowafey B, Van de Casteele E, Youssef JM, Zaher AR, Omar H, Politis $\mathrm{C}$, et al. Can mandibular lingual canals be used as a forensic fingerprint? J Forensic Odontostomatol. 2015 Dec 1;33(2):26-35.

3. İlgüy D, İlgüy M, Ersan N, Dölekoğlu S, Fişekçioğlu E. Measurements of the foramen magnum and mandible in relation to sex using CBCT. J Forensic Sci. 2014 May;59(3):601-5. doi: 10.1111/1556-4029.12376. Epub 2014 Mar 3.
4. Verma AK, Kumar S, Rathore S, Pandey A. Role of dental expert in forensic odontology. Natl J Maxillofac Surg. 2014 Jan;5(1):2-5. doi: 10.4103/0975-5950.140147.

5. Seifert Z, Friedl L, Chaumoitre K, Brůžek J. Applicability and limitations of sex assessment based on foramen magnum. Forensic Sci Int. 2017 Feb;271:126.e1-126.e9. doi: 10.1016/j. forsciint.2016.11.044. Epub 2016 Dec 8.

6. Tambawala SS, Karjodkar FR, Sansare K, Prakash N, Dora AC. Sexual dimorphism of foramen magnum using Cone Beam Computed Tomography. J Forensic Leg Med. 2016 Nov;44:29-34. doi: 10.1016/j.jflm.2016.08.005. Epub 2016 Aug 26.

7. Franklin D, Swift L, Flavel A. "Virtual anthropology" and radiographic imaging in the Forensic Medical Sciences. Egypt J Forensic Sci 2016;6(2):31-43. doi: http://dx.doi.org/10.1016/j. ejfs.2016.05.011

8. Krishan K, Chatterjee PM, Kanchan T, Kaur S, Baryah N, Singh RK. A review of sex estimation techniques during examination of skeletal remains in forensic anthropology casework. Forensic Sci Int. 2016 Apr;261:165.e1-8. doi: 10.1016/j.forsciint.2016.02.007. Epub 2016 Feb 15.

9. Gamba Tde 0, Alves MC, Haiter-Neto F. Mandibular sexual dimorphism analysis in CBCT scans. J Forensic Leg Med. 2016 Feb;38:106-10. doi: 10.1016/j.jflm.2015.11.024. Epub 2015 Dec 17.

10. Gamba TO, Alves MC, Haiter-Neto F. Analysis of sexual dimorphism by locating the mandibular canal in images of cone-beam computed tomography. J Forensic Radiol Imag. 2014;2(2):72-6. doi: http://dx.doi.org/10.1016/j.jofri.2013.12.007

11. Chandra A, Singh A, Badni M, Jaiswal R, Agnihotri A. Determination of sex by radiographic analysis of mental foramen in North Indian population. J Forensic Dent Sci. 2013 Jan;5(1):52-5. doi: 10.4103/0975-1475.114556.

12. Mohamed A, Nataraj K, Mathew VB, Varma B, Mohamed S, Valappila $\mathrm{NJ}$, et al. Location of mental foramen using digital panoramic radiography. J Forensic Dent Sci. 2016 MayAug;8(2):79-82. doi: 10.4103/0975-1475.186365.

13. Angel JS, Mincer HH, Chaudhry J, Scarbecz M. Cone beam Computed Tomography for analyzing variations in inferior alveolar canal location in adults in relation to age and sex. J Forensic Sci. 2011 Jan;56(1):216-9. doi: 10.1111/j.1556-4029.2010.01508.x.

14. Antoniazzi MCC, Carvalho PLD, Koide CH. Importância do conhecimento da anatomia radiográfica para a interpretação de patologias ósseas. RGO-Revista Gaúcha de Odontologia. 2008;56(2):195-199.

15. Nascimento Correia Lima N, Fortes de Oliveira 0, Sassi C, Picapedra A, Francesquini L Jr, Daruge E Jr. Sex determination by linear measurements of palatal bones and skull base. J Forensic Odontostomatol. 2012 Jul 1;30(1):38-44.

16. Jeon HM, Jang SM, Kim KH, Heo JY, Ok SM, Jeong SH, et al. Dental age estimation in adults: A Review of the commonly used radiological methods. J Oral Med Pain. 2014;39(4):119-26. doi: http://dx.doi.org/10.14476/jomp.2014.39.4.119

17. Priyadarshini C, Puranik M P, Uma S R. Dental age estimation methods: A review. Int J Adv Health Sci. 2015;1(12):19-25. 
18. Liang X, Jacobs R, Corpas LS, Semal P, Lambrichts I. Chronologic and geographic variability of neurovascular structures in the human mandible. Forensic Sci Int. 2009 Sep 10;190(1-3):24-32. doi: 10.1016/j.forsciint.2009.05.006. Epub 2009 Jun 13.

19. Franco A, Thevissen P, Coudyzer W, Develter W, Van de Voorde W, Oyen $R$, et al. Feasibility and validation of virtual autopsy for dental identification using the Interpol dental codes. J Forensic Leg Med. 2013 May;20(4):248-54. doi: 10.1016/j.jflm.2012.09.021. Epub 2012 0ct 10.

20. Dedouit F, Savall F, Mokrane FZ, Rousseau H, Crubézy E, Rougé $D$, et al. Virtual anthropology and forensic identification using multidetector CT. Br J Radiol. 2014 Apr;87(1036):20130468. doi: 10.1259/bjr.20130468.

21. Miranda GE, Freitas SG de, Maia LV de A, Melani RFH. An unusual method of forensic human identification: use of selfie photographs. Forensic Sci Int. 2016 Jun;263:e14-e17. doi: 10.1016/j. forsciint.2016.04.028. Epub 2016 Apr 27.

22. Kamath V, Asif M, Shetty R, Avadhani R. Binary logistic regression analysis of hard palate dimensions for sexing human crania. Anat Cell Biol. 2016 Jun;49(2):151-9. doi: 10.5115/acb.2016.49.2.151.

23. Kamath VG, Asif M, Shetty R, Avadhani R. Binary logistic regression analysis of foramen magnum dimensions for sex determination. Anat Res Int. 2015;2015:459428. doi: 10.1155/2015/459428.
24. Schmeling A, Reisinger W, Loreck D, Vendura K, Markus W, Geserick G. Effects of ethnicity on skeletal maturation: consequences for forensic age estimations. Int J Legal Med. 2000;113(5):253-8.

25. Molinari SL, Victorino FR, de Faveri M, Sant'Ana DDMG, de Miranda Neto MH. Dados anatômicos sobre o canal e forame incisivos de crânios humanos dentados e desdentados. Arq Ciênc Saúde UNIPAR. 2001;5(3):221-5.

26. Wittschieber D, Schulz R, Pfeiffer H, Schmeling A, Schmidt S. Systematic procedure for identifying the five main ossification stages of the medial clavicular epiphysis using computed tomography: a practical proposal for forensic age diagnostics. Int J Legal Med. 2017 Jan;131(1):217-224. doi: 10.1007/s00414-016-1444-y.

27. Oldrini G, Harter V, Witte Y, Martrille L, Blum A. Age Estimation in Living Adults using 3D Volume Rendered CT Images of the Sternal Plastron and Lower Chest. J Forensic Sci. 2016 Jan;61(1):127-33. doi: 10.1111/1556-4029.12990

28. Sinanoglu A, Kocasarac HD, Noujeim M. Age estimation by an analysis of spheno-occipital synchondrosis using cone-beam computed tomography. Leg Med (Tokyo). 2016 Jan;18:13-9. doi: 10.1016/j.legalmed.2015.11.004.

\section{Antonione Santos Bezerra Pinto (Corresponding address)}

Rua Maria Teresa Dutra, 90, CEP 64202-338,

Parnaíba-PI, Brasil

Fone: (86) 9415-2880

Date submitted: 2017 Aug 12

E-mail: antonione182@hotmail.com

Accept submission: 2017 Dec 13 